\title{
CONTESTING RELIGIOUS BELIEFS: THE EXPERIENCE OF THE CHAM IN VIETNAM
}

\author{
Betti Rosita Sari \\ Research Center for Regional Resources, The Indonesian Institute of Sciences (P2SDR-LIPI) \\ <betty.rositasari@gmail.com>
}

\begin{abstract}
Studies on Islam and Muslims in Vietnam are indeed very interesting to be understood and shared with other Muslims in the region. Historically, the Cham communities in Vietnam have converted over many years from Hinduism to Buddhism and to Islam. Today, the Cham communities are often associated with Islam, but this does not mean that they are all practising the same rituals. However, even though they have different beliefs and orientations, the interactions among the Cham in their own community is still in harmony. I will argue that the differences between ethnic identities and religious orientations among the Cham in Vietnam have been influenced by their interactions with outsiders and their transnational networks. This study tries to capture the religious orientations among the Cham in Vietnam and how they maintain their harmonious livelihood and social interaction in the community. Furthermore, it takes a qualitative approach through observations, in-depth interviews and review literature. The observations and in-depth interviews occurred in May-June 2014 in Ho Chi Minh City and Phan Rang Province in Central Vietnam.
\end{abstract}

Keywords: Cham, identities, religious beliefs, transnational networks, Vietnam

\section{Introduction}

Cham people in Cambodia, Vietnam, and Malaysia are often associated with Islam since Islam has become their core identity. However, Cham people in Vietnam have experienced religious conversions over a long period from Hinduism to Buddhism and Islam. Together with Hinduism, in around the 4th century, Buddhism was introduced to the portcities of Champa where the pilgrims stopped by during the monsoon. Later, in the late 7th century, the Chinese 
pilgrim Yi-Jing noted that some branches of Hinayana Buddhism were adhered to here, then from the 8th to the 10th centuries there was the gradual expansion of Mahayana Buddhism.

Islam was introduced to the Cham - one of fifty-four ethnic groups in Vietnam, by the Arab traders. According to many legends and inscriptions, the Cham familiarized themselves with Islam as early as the tenth or eleventh centuries. It is also recorded in some historical documents of the Song Dynasty (China) that Islam appeared in Champa in the late tenth and early eleventh centuries. However, only after the historical events of Champa's decline in the middle of the fifteenth century did Islam become evident in the Cham community (Nguyen Thanh Xuan 2012).

At first, Islam blended into the Cham community through culture and tradition but as time went by Cham people related with Muslims from other countries and accepted Islam from Arabia as the right Islam. Nowadays, their tradition has changed to follow Arabian culture, especially among the Cham Islam in the Mekong Delta and Ho Chi Minh City (HCM) in South Vietnam. This condition is still debatable among Cham Muslim communities in Southeast Asia, particularly in Vietnam since many old people, especially Cham Bani, still believe that old Islam is better than Arabian Islam. They believe that their culture and tradition must be preserved, rather than replaced by Arabian customs.

This study will examine the contestation of religious beliefs among the Cham community in Vietnam. First, it will explore the history of Islam in Vietnam, since, to understand the dynamics of Islam in the Cham community means to deal with the past and present conditions of the community regarding their Islamic orientation. Moreover, the dynamics of Islamic orientation of the Cham cannot be separated from the networking of Cham people in Southeast Asia or around the world. The argument of this paper is that the difference of ethnic identities and religious orientations among the Cham in Vietnam have been influenced by their interactions with outsiders and their transnational networks since the access and networking among Cham around the world have developed and strengthened.

This paper is divided into four parts with the first dealing with the history of Islam in the Cham community; The second part examines the evolving dynamic of Islam in Cham communities; The third discusses Islamic networking and contestation of religious beliefs of the Cham in Vietnam; and the last part considers the predictions for the future of the Cham in Vietnam. 


\section{History of the Cham in Vietnam in relation to the influences of Islam}

The Cham is a Malayo-Polynesian ethnic group in Vietnam with a culture and language that bear great affinities with those of peoples from Malaysia, Indonesia and the Philippines. They were the earliest inhabitants of the area of southern Vietnam. Champa, the kingdom of the Cham, existed from 700-1471 C.E and was composed of five territories: Indrapura, Vijaya, Kauthara, Panduranga and Amaravati. Different from the Cham in Cambodia and Malaysia who share the similar experiences of becoming refugees and exiled people, the Cham in Vietnam, although some had similar experiences as refugees, the majority continued in Vietnam, especially the Cham in Central Vietnam. This situation, of course, influences the construction of Cham identity in Vietnam and also their transnational networks. The Cham in Vietnam who remained behind were isolated by successive Vietnamese dynasties from the Islamized Malay world, with which they shared a common religion and culture and, to a lesser degree, language. With the incorporation of Vietnam into the French Colonial Empire during the nineteenth century, all official assimilation policies stopped and were replaced by a policy of benign neglect. Under the French, the Cham found themselves in two different colonies: Cochin China in the south and Annam in the center. As a result, the communities gradually became quite distinct from each other. This remains the case today and has resisted all attempts at achieving ethnic unity (Willoughby 1999).

According to the official statistics of 1979 , the Cham were officially considered one ethnic group out of 54 in Vietnam, where the majority are ethnic Kinh accounting for approximately $87 \%$ of the total country population, the remaining $13 \%$ are minority ethnic people (Schliesinger 1997). Historically, the Cham were divided along religious lines: Hindu and Muslim. The Muslim population is subdivided further between the Cham Banis and the mainstream (Sunni) Cham Islam. The Cham population is concentrated mainly in the lower middle and southern parts of Vietnam. In the middle part, they live scattered in the Phan Rang and Phan Ri regions. In the southern and south western parts, they live in Tay Ninh, Chau Doc, An Giang, Ho Chi Minh, Long Khanh, and Binh Phuoc cities. The Cham Banis and Cham Hindus only reside in Phan Rang and Phan Ri. There, the Cham Banis make up about one-half of the Cham population, while the remaining half is Cham Hindu. However, in the south and south west, all of them follow mainstream Islam (Ba Trung Phu 2008). Whereas, the Cham communities in the Mekong Delta live in 9 communities comprising from 700-3000 people in each one, most 
situated along the Mekong River (sông hau) and around Chau Doc market, which is located near the Cambodian border (Huynh Van Phuc et al 2011). The Muslim Cham in Cau Doc host the local Institute of Higher Islamic Studies and practise an orthodox form of Islam, similar to Malay practices. Teaching is supplemented by village elders and others who have some Islamic knowledge.

\section{The Appearance of Islam in Champa and the Dynamics of Islam in Cham communities in Vietnam}

As mentioned previously, based on a Chinese record, Islam entered Champa during the tenth century: "There were many water-buffalos that lived on the mountain (in Yin Li) (Huber 1903). They (the buffalos) were not used to cultivate the land but as sacrificed objects to the Gods. When the waterbuffalo was killed, they invoked the name 'Allahu Akhar.' Additionally, Aymonier found this paragraph in the record left by an anonymous historian of Champa:

In the year of the mice, a man who attributed himself to Po Auloah (Allah) worked for betterment and perfection of Champa. But the people became upset. He then submitted himself wholly to God, migrated to live in the holy land of Mecca. Later, he returned to the kingdom in the reign of the king whose name is Ouloah (Allah) that ruled the land from 1000 to 1036 .

This paragraph is carved, along with its Sanskrit translation, on two stones found by an archaeologist working along the coast of Central Vietnam. One stone is dated 1039 and the other between 1025-35. The writings on both stones mention Muslims but indicate that they are foreigners who stay along the coast in the middle of present-day Vietnam. Most of them were traders and builders who formed their own communities with a spiritual leader and a man who led the prayers, whom they called emüm (imam). Based on archaeological artifacts and historical data, some historians have concluded that Islam entered Champa perhaps as early as the tenth century.

Meanwhile, Nakamura (2008:8) defines that the first existence of Muslim communities was in the 8th century, located in South Central Vietnam. She argues that Islam in Vietnam, especially on the coastline of Central Vietnam, was brought by Middle Eastern traders along the silk road of the sea to China. At the same time, Musa (2004: 48) states that Islam was introduced to Vietnam in the 11th century by the Arab and Persian traders who at the same time introduced it to the Malay Archipelago. But the progress of the acceptance of Islam in Champa was very much faster than that in the Malay Archipelago as vestiges of Islam have been found only in the Cham area.

Another source argues that in the 
first millennium B.C.E., the Cham had sailed from the west coast of Borneo across the East Sea (or the South China Sea) and settled in what is now Central and South-Central Vietnam (Angie Ngoc Tran 2016). According to Nakamura (2000), there were two waves of Muslim arrivals in Champa. Persians, Arabs, Indians and Chinese Muslims were the first Muslims who came to Champa in the ninth century and established a presence there by the eleventh century. At that time, conversion to Islam was limited to people who enjoyed special relationships with the foreign communities. The second wave comprised Malay Muslims who had contacts with the Cham during the peak of Southeast Asian maritime trade in the sixteenth and seventeenth centuries. This was the time when a significant number of the local population converted to Islam. Like the contemporary Sunni Muslim Cham in Giang Province in Vietnam, a province bordering Cambodia, with close associations with Cham Muslims in Cambodia. They speak the same dialect and some have kinship ties. Moreover, the Malays were responsible for converting the Cham refugees to Sunni Islam with both the Cham Muslims and Malay Muslims following the same school of Islam (Shafi'i) and sharing similar religious customs (pp. 63-64).

In an interview with Cham scholars in Vietnam, $\operatorname{Han}^{1}$ states that there was an inscription in Jawi that explains Islam already existed in the Champa Kingdom around the 9th and 10th centuries in Phan Rang. However, he claims that this does not mean that Cham people also converted to Islam. Furthermore, Han contends that after the decay of the Champa Kingdom in 1832, the majority of the Cham people immigrated to Cambodia, Thailand and Lao PDR. Some, who were fishermen, migrated to Malaysia and Indonesia. In Cambodia, the Cham lived among the Malayan community (with the same Malayo-Polynesian languages) who followed Islam. Therefore, the majority of them were gradually converted from Brahmanism to Islam. These Cham people later came back to their native land in Vietnam and tried to persuade the rest of the people to leave Brahmanism to follow Islam. However, since the Cham in Vietnam, at that time, were still under the great influence of the remnants of matriarchy and Brahmanism - their main religion, this Islamic propagation gained very few converts. As a result, half of the Cham people here still followed Brahmanism. This condition is different from that of the Cham people who immigrated to Malaysia and Indonesia because they seem to have lost their identity as Cham and as time went by to identify themselves as Malay and not be eager

1 Interview with Samad Han, May 13, 2014, Ho Chi Minh City, Vietnam 
to go back to their ancestral land (field interview with $\mathrm{SH}$, Cham scholars in $\mathrm{HCMC}$ ).

As a result of differences in geographical location, missionary context, living conditions and level of exchange with the outside world, first and foremost the Islamic world, two different Cham communities following Islam were formed in Vietnam.

According to Yoshimoto (2012) they are divided into two main groups: one, the Muslims living in Ninh Thuan and Binh Thuan Provinces in South-Central Vietnam, known as "the Old Islamic Group," "Cham Bani," or "Bani”; two, the Muslims living in An Giang, Tay Ninh, and Dong Nai Provinces around the Mekong Delta, as well as in Ho Chi
Minh City, known as "the New Islamic Group," "Cham Islam," or "Islam" (Table 1).

The religious beliefs among the Cham community in Vietnam can be categorized into:

\section{Cham Ahier or Cham Jat (Original} Cham)

Hinduism was the first religion adopted by the Cham at the establishment of the Champa Kingdom. Hindu temples are known as Bimong in the Cham language but are commonly referred to as tháp "stupa", in Vietnamese. Quoting from Cabaton (1907): among the Cham who believe in Brahmanism - their practices have little resemblance with those in India and they call themselves Cham Jat or Cham

Table 1. Muslims in Vietnam

\begin{tabular}{|c|c|c|}
\hline & Islam (Cham Islam), New Islam & Bani (Cham Bani), Old Islam \\
\hline Branch & Sunni & Bani \\
\hline Place of living & $\begin{array}{l}\text { An Giang Province, Tay Ninh } \\
\text { Province, Ho Chi Minh City, Dong } \\
\text { Nai Province, Ninh Thuan Province }\end{array}$ & $\begin{array}{l}\text { Ninh Thuan Province, Binh } \\
\text { Thuan Province (old territory of } \\
\text { Panduranga-Champa) }\end{array}$ \\
\hline $\begin{array}{l}\text { Authorized } \\
\text { organizations }\end{array}$ & $\begin{array}{l}\text { Ho Chi Minh City Muslim } \\
\text { Community } \\
\text { Representative Committee (1992 ) } \\
\text { An Giang Muslim Community } \\
\text { Representative Committee (2004 ) }\end{array}$ & $\begin{array}{l}\text { Bani Religious Leaders Council } \\
(2006 \sim)\end{array}$ \\
\hline Population & 25,000 & 41,000 \\
\hline Places of worship & 41mosques, 19 surao & 17 thang mugik \\
\hline Religious clerics & 288 & 407 \\
\hline Religious features & $\begin{array}{l}\text { Islamic rules and rituals are fully } \\
\text { observed; pilgrimages to Mecca; } \\
\text { networks with Malaysia, Indonesia, } \\
\text { and Saudi Arabia }\end{array}$ & $\begin{array}{l}\text { Strongly influenced by local, } \\
\text { traditional customs and beliefs } \\
\text { and incorporated elements of } \\
\text { Brahmanism and matriarchy; no } \\
\text { pilgrimages }\end{array}$ \\
\hline
\end{tabular}

source: Yoshimoto 2012 
Harat (Pure race) (Musa 2004). By calling themselves by such a name, they mean to differentiate themselves from the Muslim Cham. Among the Cham Islam, they are also known as Akafir or Kafir (Impure), a deformation from an Arabic word Kafir which mean infidel.

As a consequence of an interview with scholars in Ho Chi Minh City, VD ${ }^{2}$ states that the traditional Cham group live in the mountain areas, Binh Dinh and Phu Yen Provinces. They usually do not follow a religion but adhere to the traditions of their ancestors. There are around approximately 20,000 Cham people there. Distinct from the Cham Bani, another group, the Cham Ahier, practise, a syncretic form of Hinduism, observe taboos about eating beef, cremate their dead and are led by a priest called 'Halau Tamunay Ahier' (Willoughby 1999).

The Cham in Binh Dinh and Phu Yen Provinces have settled in areas of grassland in small houses on stilts, with floors $1 \mathrm{~m}$ above the ground and a door on one of the longer sides. At each end of the ridge of the roof, a letter $\mathrm{V}$ can be seen, formed by the two "horns of the house" (chke vang) which are the extensions of the two main rafters. The houses of the Cham Hroi group are smaller (about $8 \mathrm{~m}$ long and $4 \mathrm{~m}$ wide) adapted to their ancient nomadic way of life and culture.

In the past, the Cham people used to be sea people involved in maritime

2 Field interview with VD, 14 May, 2014, in his office trade. Nowadays, they are living inland and engaging in wet rice cultivation. Agriculture and gardening provide the main income for the Cham in Central Vietnam. They are engaged in cultivating crops such as sugar cane, maize, bananas, coconut trees, beans, peppers, as well as betel leaves, which are chewed to produce a mild stimulant. Most of the Cham in Central Vietnam do not practise rice paddy agriculture that is widespread in other regions of Vietnam. They have domestic animals such as buffaloes, chickens, ducks, and goats. As Muslims, they do not raise pigs. They also abstain from eating dogs, tortoises, crocodiles, elephants, peacocks, vultures, eagles, crows, and drinking alcohol (Dang Nghiem Van 1993). Traditionally, Cham males in Vietnam do most of the agricultural labor in the fields, while women engage in domestic duties such as housework, cooking, caring for children, preparing food and weaving beautiful cloths. Some villages specialize in making certain kinds of products such as pottery and textiles. With the development of tourism in Vietnam, indigenous hand woven textiles and pottery have become quite popular and the Cham traditional weaving has been revived (Nakamura 2008).

\section{Cham Bani}

Cham Bani or Cham Assalam are the Cham who had converted to Islam. The word Bani is from an Arabic word beni which means son, or son of the true 
faith. Cham Bani have been degraded and become unorthodox due to the influence of local manners and customs over the religion, including Brahmanic beliefs and matriarchy (Musa 2004). This situation has resulted in incorrect Islamic awareness. Similarly, Yoshimoto (2012) reveals that they are strongly influenced by local and traditional customs and beliefs and have incorporated elements of Brahmanism and ancestor worship. They also have very limited contact with other Muslims outside Vietnam.

With the exception of religious practices, there is no difference between the Cham Akafir and the Cham Bani. The difference lies only in the practice of their religion; not in their social organization. Generally, the Cham Bani do not care much about whom they marry, a Muslim or a non-Muslim, neglect their ablutions and the five daily prayers and do not practise circumcision. Their conduct is more like that of an unbeliever than a Muslim. For them, the respect of the obligations and interdictions of the Koran are not very important as they believe that they can amend any wrong doing by the purification (atau ra). In an interview $\mathrm{Krisna}^{3}$, a young Cham Bani and university student in HCMC states that Bani is a mix of Islam and tradition where they can delegate the responsibility to pray or fast to an imam

3 Interview with Krisna, 15 May, 2014, in Ho Chi Minh City in their family. Every Bani family has one representative as an imam. Nowadays, many young Cham Bani do not follow religious practices, such as fasting and praying and even eat pork which is forbidden in Islam. The interesting fact is, even though they are not religious, most of them will come back to their ancestral land in the Ramawan (Ramadhan) and carry out traditional rites. Moreover many Cham Bani have now converted to Islam.

The Cham Bani live predominantly in Vietnam's Bình Thuận, Ninh Thuận and Bình Phước Provinces, the remnant of the Champa Kingdom. They are proud of their historical heritage and worship deified kings and practise their old rituals in Po Nagar. They have kept their traditional writing system which has evolved from the Sanskrit. The Cham Bani practise a syncretic form of Islam and worship Po Alwah (Allah) in the mosque which they call Thang Muki which is only open in the Ramadhan month on the Islamic calendar. They do not eat pork, bury their dead and are led by a religious head called Halau Tamunay Awar. The Cham Bani call Ramadhan 'Ramuwan,' which takes place around the same time as the Ramadhan. Three days before the first day of Ramadhan, the Cham Bani engage in ceremonies and visit ancestral graves (Nakamura 1999).

The Cham Bani in Ninh Thuan and Binh Thuan prefer to live away from the Kinh (majority Vietnamese) people. 
From the historical point of view, the Kinh people are the latecomers who migrated into the land of Champa. The Cham usually form their villages a little away from the provincial capital, markets and the major roads where the Kinh population usually concentrates. Each village comprises several hundred inhabitants, sometimes up to a thousand. The houses are arranged in orderly rows each surrounded by a garden with a wall or hedge. The Cham villages are ringed by rice fields and vineyards and often one has to cross a small stream before entering the village. The people are engaged in agriculture, raising animals and husbandry, as small-scale traders, making handcrafts and pottery and so on. The Cham Bani handcraft and weaving products are sold to the tourist centers in Nha Trang or Ho Chi Minh City as souvenirs.

\section{Cham Islam}

As mentioned previously, in the mid 10th and 11th centuries Champa became a busy commercial port, a bridge of trade in the region. Muslim traders from the Arabian Peninsula and the Middle East were the first to bring Islam to Champa. Until the 15 th century, Champa was not only a trading center for Muslims of other countries but also an ally of other Islamic communities in Southeast Asia. By the 1670 s, the bulk of the population, including the Cham royalty, was Muslim.

Cham Islam is usually described as of followers of Hồi giáo mới in Vietnamese, which means "new Islam," or Cham biraw in Cham, which means "New Cham." According to previous studies, "New Islam" began to emerge in the 1960s when some of the Cham Bani were exposed to the practice of Sunni Muslims in places such as Saigon (now Ho Chi Minh City). Realizing that their own religious practices were not authentic, they began to aim for purer Islamic practices (Nguyễn 1974: 272; Nakamura 1999: 104). After their conversion, the converts abandoned ancestor worship and with the aid of the Islamic community from outside, built mosques in their villages (Dohamide 1965: 56; Yoshimoto 2010: 243). This group brought a new Islamic orientation among the Cham which is commonly found in Islam around the world.

The Cham Islam developed very well and widely in Cau Doc, Ho Chi Minh City, Tay Ninh and Dong Nai Provinces in South Vietnam with a population of 13,000 Cham (Taylor 2006: 238). The religious activities here are orthodox and eventful. The Islamic canon laws and rituals are fully obeyed, in particular, the Islamic community here has connections to the Islamic world through their pilgrimages to Mecca and send their children to schools in Malaysia, Indonesia, and Saudi Arabia. These activities have helped Islam to remain relatively intact. In the past, Chau Doc was considered a miniature version of the Islamic world 
in French dominated Indochina. From the Islamic center of Chau Doc, Islamic education has spread widely, even to areas like Cambodia.

The Vietnamese Cham Muslims adhere to the Sunni Islamic school of thought, which is similar to their counterparts in Cambodia, Malaysia, and Indonesia. Even their lifestyles and customary practices reflect this common trend of Islamic belief. For instance, Muslim communities in all these places are called "kampongs". Muslim men wear "batik lungi" tied in a knot at the waist. But while the "songkok" (black Muslim cap) is popular in Indonesia and Malaysia, the Cham of Vietnam and Cambodia wear white skullcaps called "kapea" The elders among the Cham wear white robes and turbans "sunnah".

Yoshimoto (2012: 491) states that some of the Cham Bani in HCMC were exposed to the practice of Sunni Islam around 1960 by other Cham Bani who came from Malaysia and Cambodia. In support, VD argues that in around 1960, there was a man who had finished his study in UEA and lived in Anh Giang. ${ }^{4}$ He brought the "new Islam" and built a different place of worship, which he called a mosque. As a consequence, there have been two Islamic groups in Anh Giang since then. YS, cham people in HCMC contends that 'new Islam' was introduced to some communities in HCMC after one Bani who had graduated from Malaysia University

4 Interview with VD, 14 May, 2014. and after 10 years of living in Malaysia came back. ${ }^{5}$ In a similar vein, $\mathrm{SH}$ argues that most Muslims in Vietnam follow Safii Mazhab. However, he also states that some Muslim extremists try to bring their thoughts to their homeland but they encounter resistance from the elderly. ${ }^{6}$

At the same time, Maryam ${ }^{7}$ contends that Islam from Arabia was introduced to her village in Phan Rang from Cambodia around 4 years ago since they have relatives who live in Cambodia. At first, most of the villagers refused to accept this religious teaching, however, in time, many villagers followed it. Although, as Cham Muslims they have accepted the teachings of Islam, they still try to maintain their traditional customs and practices. In an interview, Ismael, a Cham Bani in Chan Vang village who converted to Islam declared that:

We live together as Muslims in the same community because we have different lifestyle and practices from the other Vietnamese. Even though we have different religious beliefs, one Cham Bani and the other Cham Islam, but we are a family. Moreover, We, the older generation must also be careful not to lose our Cham cultural heritage.

YT, head of Islamic Representation in Ninh Thuan, stated that in around 1960, many Cham Bani converted to Cham Islam. Most of them were Cham

5 Interview with YS 13 May, 2014.

6 Interview with SH, 13 May, 2014.

7 Interview with Maryam, 17 May, 2014. 
Bani who worked in Cau Doc on South Vietnam's border with Cambodia. They saw religious practices that differed from their rituals and believed that this was the "right" Islam. ${ }^{8}$ Since then, many Chams, especially in Central Vietnam, believe that "new Islam' is "the right Islam", and they have to follow it.

"The right Islam" means they have to follow the five pillars of Islam: 1) Shahadah, the declaration of faith, stating there is no god but God and that Prophet Muhammad (pbuh) is the messenger of God); 2) solat, the five daily prayers; 3 ) zakat, the personal taxes paid during Ramadhan and on wealth and shadaqah, charity; 4) sawm, Ramadhan fasting; and 5) haj, the pilgrimage to Mecca. The last is mostly observed by those who are financially and physically able to do so. ${ }^{9}$ Besides practising the five pillars of Islam, Cham Muslims observe other important Islamic religious festivities and other aspects of Cham culture, including Eidul Adha (Islamic New Year), Mawlid (Muhammad's Birthday), and ziarah (visitation to the grave of religious figures and their loved ones). The funeral ceremony is important for Cham Muslims. In Islam, it is imperative that the ceremony, along with ritual prayers for dead bodies, be prepared in a religiously appropriate manner so

8 Interview with YT, 18 May, 2014

9 An oral history of Cham Muslim women. that the dead bodies can rest in peace. ${ }^{10}$ In addition, the new Cham community built its own mosque and Qur'anic school where religious teaching is given in Arabic and Malay.

\section{Transnational networks and Con- testation of religious beliefs of the Cham in Vietnam}

The Cham people established extensive and intense webs of relationships that encompassed activities in the economic, religious, cultural and political spheres throughout maritime Southeast Asia. Moreover, The Cham of Southeast Asia were not completely isolated from other areas of the Islamic world. As mentioned earlier, there were contacts between the Cham of Vietnam and Cambodia and their religious brethren in the MalayanIndonesian world. In addition, some of the Cham traveled to the Middle East in order to be exposed to the Islamic traditions in that region. In so doing, they began to bring back to their home countries Islamic beliefs and practices that eventually shaped the indigenous forms of Islam in their regions (Scupin 1995).

The Malayan and Malaysian Islam have a great effect on Cham Muslims. Although there are not many Malayans living amongst Muslims in Chau Doc, their influences are still significant in many ways, from social structures to religious activities. In the past, the

10 An oral history of Cham Muslim women. 
Koran was read in Arabic but recited in Malay. Islamic dignitaries and Koran teachers were mostly Malays. Most religious publications were also imported from Malaysia. Even the new religious movements were under the influence of the new religious movement in Malaysia. However, the influence of the Malays on Islam in different areas are not equal, being deepest in Chau Doc but less profound in Ho Chi Minh City and Dong Nai (Nguyen Thanh Xuan 2012).

The Muslim Cham have greater economic and social status because of the economic links they have with other Muslim countries such as Malaysia, Indonesia, and some countries in the Middle East. Bjorn Blengsli in an article entitled "Trends in the Islamic community", points out the existence of Arab charities such as the Om Al Quran Charity Organization and the Islamic Heritage Society that have set up schools and mosques around Cambodia, including opportunities to study abroad or perform the pilgrimage to Mecca. However. what is more significant is that the Muslim Cham ride on linguistic, cultural, and historical affinities with peoples of the "Malay world". The Cham capitalized on the perception of the Malaysian government that the Cham were "cousins" of the Malays. An interview with YS highlights some features of this. Through such perceptions, the Muslim Cham garnered a greater degree of economic opportunities in such countries than they would have if they were Hindu Cham. Therefore the Cham, following the logic of the Instrumentalists, use their ethnicity to further their interests, socio-economic survival being one of them (Effendy 2007).

SH states that there are a lot of funds from Cham Muslims around the world for Cham people in Vietnam, in regard to scholarships, mosque buildings, pilgrimages, etc. ${ }^{11}$ YS is a Cham funded to do the hajj pilgrimage by the UEA. He explained that every year, around 40-50 Cham people in Vietnam make a pilgrimage to Mecca with funds from the UEA through the mosque community. ${ }^{12}$ Vietnam's largest mosque was opened in January 2006 in Xuan Loc, Dong Nai Province; its construction was partially funded by donations from Saudi Arabia. Moreover, Dewi argues that there are lots of funds from Muslim organizations for Cham in Vietnam, for example, IDB (Islamic Development Bank) gives scholarship for graduate and postgraduate degrees. ${ }^{13}$

The networking is not only concerned with religious matters but also in terms of socio-economics. Mohamed Effendy Bin Abdul Hamid (2007) states that the Cham have established transnational networks in pursuing economic, cultural and political purposes all around Southeast

11 Interview with SH 13 May, 2014.

12 Interview with YS, 13 May, 2014.

13 Interview with Dewi, 14 May, 2014. 
Asia. In support, $\mathrm{SH}$ contends that the relations among the Cham in Southeast Asia have been dominated by trading. They have great networking with Cham in Cambodia, Malaysia, and Indonesia, especially in Muslim wares, including clothing, headscarves, prayer mats, tudung, baju kurung, head caps, etc. Many Cham outside Vietnam share financial capital with the Cham in Vietnam to open a halal restaurant, sell Muslim wares and open travel agencies. ${ }^{14}$ As Vietnam moved to a market-based economy, the Cham became disadvantaged locally (compared to the Kinh majority) in their economic ventures but they have been successful extra-locally in making their living by moving across national borders and within Vietnam. According to Taylor, the Cham "reinvent economic space through local and extra-local trading practices that draw upon and also sustain their distinct cultural competencies and institutions" (Taylor 2006: 248).

Effendy's study (2007) reveals that the Cham use a "religious layer", or the perception of other Malay-Muslims of their "Muslimness", allowing the Cham to participate in the social networks, establish personal relationships and engage in certain processes within predominantly Malay Muslim countries, such as Malaysia and Indonesia. He finds that the Cham, especially the Muslim Cham (while the majority are

14 Interview with SH, 13 May, 2014.
Muslims, some Cham are Hindu), have been using their own ethnic passport for some time now in countries such as Malaysia and Indonesia where they travel mostly for work, study and business. There are large Malayspeaking and predominantly Muslim populations.

Networking among Cham Muslims is not limited to Southeast Asia but practised all around the world. One of the examples is Abdul Halim bin Ahmad, YT's uncle who moved to the USA and studied Islam in the UEA. When Vietnam won its freedom in 1975, he was asked to choose his citizenship and opted for the US. Now, he teaches Islam there and gives scholarship information to family and fellow Muslims in Vietnam. From this story it is clear, the networking of Cham is not only among Cham people or Muslim organizations in Southeast Asia but also among Cham and Muslim organizations around the world.

Another aspect is the proliferation of religious missionary activities in Vietnam, bringing spiritual aid to the country. This is because most of the missionaries from abroad hold the view that the Cham Muslims in Vietnam, especially the Cham Bani in Central Vietnam, do not adhere sufficiently to Islam and thus are in need of purification. Each Muslim sect from outside Vietnam wants the Cham to accept its theology, such as Jamaah Tabligh, Da'wah, etc. During our field 
work in Phan Rang, we saw some missionaries from the Jamaah Tabligh group reside in the mosque in a Cham Bani village. They came from several countries, including India, Pakistan, and Malaysia. They stayed there for one week to spread Islamic values and then moved to other villages. According to our interview with Ismael, the Imam in the mosque, the Cham community accepts them warmly but we do not have much information whether all of the villagers followed their teaching because the majority of the villagers are Cham Bani though some of their family members have converted to Cham Islam already. ${ }^{15}$

In Cambodia, the existence of an Islamic movement from abroad has sometimes led to conflicts within Cham communities, for example, the conflict between Chumnik and Soay villages in Kampong Cham Province when two or three different sects competed for followers in the same village (Osman 2010). The Cham were told that their traditional practices are not very pure and that they must now adopt other ones which are the purest. When hearing this, some decided to accept one new practice, while others accepted others. Each group then considered that it was the best practitioner of Islam.

Moreover, Sari's study finds that some charity organizations from Arab countries, Pakistani, Thailand, and Malaysian sources provide funds to develop a community with some conditions for them to follow their Islamic practices (Sari 2013). On top of that, Malaysia is the most influential in shaping the Sunni Muslims of Cambodia by offering opportunities for young Cambodian Muslims to further their studies. In February this year, 19 Muslims were awarded scholarships to study Bachelor and Master Degrees sponsored by the Al-Manar Islamic College in Malaysia. Apart from education, the Malaysians have given large grants to support the Islamic Institute at Boeng Kak Mosque in Phnom Penh. Malaysian government aid also supports a women's center and clinic at Kilometre 7, in the middle of Cham-Chvea communities found along National Route 5, north of Phnom Penh. The Malaysian government has supplied the women's center with both sewing machines and looms to teach poor Muslim women income generating skills. The association also provides training for women in family health practice and Malay language to increase female literacy and to improve access to contemporary books in Malay. The continuous support and productive relationship between the two countries have been in existence for decades resulting in intermarriages with the Malay community. Today most Cham speak the Malay language with many of them adopting Malay customs as their own.

15 Interview with Ismael, 14 May, 2014. 


\section{Conclusion: Future Predictions for the Cham in Vietnam}

The Cham communities in Vietnam have frequently converted from Hinduism to Buddhism and to Islam. Generally, the Cham can be divided into three mainstreams: the Cham Jat or Ahier, Cham Bani and Cham Islam. The Cham Ahier and Cham Bani are concentrated in Central Vietnam. Both of them still practise traditional rituals and do not have many contacts with outsiders. On the other hand, Cham Islam are mainly located in $\mathrm{Ho} \mathrm{Chi}$ Minh City and some provinces in the Mekong Delta. They received a lot of influences from the Cham in Cambodia and also from the Islamic brotherhood in Malaysia and Indonesia. Indeed, the dynamic of Islamic orientation of Cham in Vietnam could not be separated with their networking with Cham people in Southeast Asia and around the world.

The condition of the Cham in Vietnam began to change after the emergence of the dakwah movement in Southeast Asia. This happened in three countries, Vietnam, Malaysia, and Cambodia with the rise of Islamic education from The Middle East. Many Cham joined dakwah schools and brought the new understanding of Islam to their communities. Furthermore, many in the young generation believe that the Middle Eastern perspective is the Right Islam. At first, this new way was rejected by the older generation, however, as time passed the change was gradually accepted, especially among the younger people.

In Vietnam, the number of Cham Islam is growing significantly since they have access to transnational networks with Muslims in Malaysia, Indonesia, and the Middle East in terms of Islamic education, economics, and social welfare. As Vietnam moved to a marketbased economy, the Cham became disadvantaged locally (compared to the Kinh majority) in their economic ventures but they have been successful extra-locally in making their living by moving across national borders and within Vietnam. Many Cham in South Vietnam are becoming traders and workers in Malaysia, supported by previous Cham who moved to Malaysia. The ethnic networks and similar identity as Cham people are being used when they travel mostly for work, study and business to Malaysia or Indonesia. There are large Malay-speaking and predominantly Muslim populations in those countries.

Indeed, in terms of identity, the widening of networks among the Cham communites has brought about their identities. For instance, some Cham who have been associated more with Malaysia, tend to identify themselves as Malay-Cham. While, other Cham groups like Cham Bani have not related closely with Malaysia and therefore, are not associated with the Malay but rather associated with the Cham of Vietnam, the "pure Cham". 


\section{Question and Answer}

Q: Why are Cham Bani in Central Vietnam not greatly influenced by the transnational islamic movement, such as Jamaah Tabligh?

A: I think, on the contrary, the Cham Bani in Central Vietnam are the target of the Jamaah Tabligh group since they believe that the Cham Bani still practise traditional rituals, not purely Islamic teaching. Moreover, the Jamaah Tabligh is still limited in number and can not reach all of the Cham Bani in Ninh Tuanh and Binh Tuanh Provinces. On the other hand, the economic status of the Cham Bani is lower than of the Cham Islam in South Vietnam because they are engaged in agriculture, raising cattle and other subsistence economic activities, so they do not have many resources to travel abroad and have contact with outsiders.

\section{Acknowledgments}

I'd like to acknowledge Research Center for Regional Resources-LIPI which provided funds for the research project on the Cham Diaspora in Southeast Asia: Construction of Identity and Transnational Networks in Vietnam in 2014. Comments and feedback from "IFSSO International Seminar on Global Connectivity: Challenges and Responses" participants on September 10-13, 2017 in Denpasar, Bali. were very helpful. Finally, I would like to thank the team members of this research, Prof Dr Yekti Maunati and Amorisa Wiratri, MA for their comments and support of this article.[]

\section{References}

Angie Ngoc Tran. 2016. Weaving Life Across Borders: The Cham Muslim Migrants Traversing Vietnam and Malaysia in K.F. Lian et al. (eds.), International Migration in Southeast Asia, Asia in Transition 2, DOI 10.1007/978-981-287-712-3_2

Ba Trung Phu. The Cham Bani of Vietnam. Accessed from https://religiondocbox.com/ Islam/70316706-The-cham-bani-of-vietnam.html on September 16, 2018

Ba Trung Phu. 2008. Bani Islam Cham in Vietnam. CIAS discussion paper No.3 : Islam at the Margins: The Muslims of Indochina (2008), 3: 24-33

Dang Nghiem Van and Chu Thai Son. 1993. Ethnic Minorities in Vietnam. Hanoi: The Gioi Publishers

E. Huber, "Note sur un témoignage de l'islamisation du Campa," Annales des Song (1903).

Huynh Van Phuc, Somchai Phatharathananunth, Srisakra Vallibhotama, and Khwanchewan Buadaeng. 2011. The Adjustment of the Muslim Cham Female in Vietnam's Mekong Delta to the Cultural Policy and Economic Changes after Doi Moi Policy. European Journal of Social Sciences Vol.27 No.1 (2011), pp. 25-33. Retrieved from http://www. europeanjournalofsocialsciences.com/issues/EJSS_27_1.html on November 13, 2014

Jay Willoughby. 1999. The Cham Muslims of Vietnam. Regional Issues ISIM Newsletter 2 / 1999

Musa. 2004. Islam as Understood and Practiced by the Muslims in Indochina. Journal 
Islammiyat 25 (1) 2004: 45-60

Mohamed Effendy Bin Abdul Hamid. 2007. Revisiting Cham Ethnic Identity in Vietnam and Cambodia: The Concept of "Ethnic Passport". Unpublished Thesis. Singapore: National University of Singapore

Nguyen Thanh Xuan. 2012. Religions in Vietnam. Hanoi: The Gioi Publishers

Nakamura. 2008. The Cham Muslims in Ninh Thuan Province, Vietnam. CIAS Discussion Paper No. 3. In Islam at the Margins: The Muslims of Indochina. Edited by Omar Farouk and Hiroyuki Yamamoto. Kyoto: Center for Integrated Area Studies

Nakamura. 1999. The ethnicity of the Cham in Vietnam. Accessed from http://journalarticle. ukm.my/384/1/1.pdf on September 12, 2018

Schliesinger, Joachim. 1997. Hill tribes of Vietnam, Volume 1 - Introduction and Overview. Thailand: White Lotus Press.

Scupin. R. 1995. Historical, Ethnographic, and Contemporary Political Analyses of the Muslims of Kampuchea and Vietnam. SOJOURN Vol. 10, No. 2 (1995), pp. 301-28

Sari, Betti Rosita. 2013. 'Cambodian Cham Muslims and the Islamic World: Towards a Transnational Network' in Yekti Maunati and Betti Rosita Sari (eds.) The Cham Diaspora in Southeast Asia: Social Integration and Transnational Networks: The Case of Cambodia. Jakarta: LIPI Press.

Taylor. P. 2006. Economy in Motion: Cham Muslim Traders in the Mekong Delta. The Asia Pacific Journal of Anthropology Vol. 7, No. 3, December 2006, pp. 237 _250

Willoughby. J. The Cham Muslims of Vietnam. ISIM Newsletter 2/ 99. Retrieved from https://openaccess.leidenuniv.nl/bitstream/handle/1887/17164/ISIM_2_The_Cham_ Muslims_of_Vietnam.pdf?sequence=1 on November 20, 2014

Yoshimoto. Y. 2012. A Study of the Hồi giáo Religion in Vietnam: With a Reference to Islamic Religious Practices of Cham Bani. Southeast Asian Studies, Vol. 1, No. 3, December 2012, pp. 487-505 487. Kyoto University: Center for Southeast Asian Studies

Ysa Osman, 2010, Navigating the Rift: Muslim-Buddhist Intermarriage in Cambodia. Cambodia 